\title{
Stagnation in housing production: another success in the Dutch 'planner's paradise'?
}

\section{Willem K Korthals Altes}

OTB Research Institute for Housing, Urban and Mobility Studies, Delft University of Technology, Jaffalaan 9, NL 2628 BX Delft, The Netherlands; e-mail: w.korthalsaltes@otb.tudelft.nl Received 21 April 2004; in revised form 5 February 2005

\begin{abstract}
There are a number of different criteria for measuring the success of plans in planning. In the planning literature there is a debate about the criterion of conformance (that is, whether spatial development is according to plan) as opposed to performance (that is, whether the plan has shown the way to better decisionmaking), which is, in fact, different from performance measurement. In this paper both criteria are applied to measure the success of Dutch national concentration policies in the "Fourth Memorandum on Spatial Planning-Plus". The author shows that the urban containment policies conform well to the plan but perform badly in terms of improving current decisionmaking on the stagnation of housing production in the Netherlands. Moreover, the present stagnation of housing production is planned stagnation. With this result, the author shows that conformance and performance are independent criteria for measuring planning success, and that plans (as set out in the "Fourth Memorandum on Spatial Planning-Plus") with high conformance may still perform badly on the performance criterion.
\end{abstract}

\section{Introduction}

The ability to assess success in planning is crucial for planning studies as the degree of success is a critical reflection of planning practice. Planning success is usually measured according to the conformance between the plan and its outcome, because this shows how well the plan and the planning agency predicted or controlled future developments. However, planning often takes place in an uncertain context, with multiple players, with the planning agency learning through time, so conformance of later developments to the plan may indicate that the learning process has failed; thus in uncertain conditions conformance is not always the preferred criterion. Alternative ways of conceptualising success have been introduced. One of these alternatives relates to the performance of the plan as a means of improving subsequent decisions by the planning agency. This concept differs from the popular notion of performance measurement as a way of reinventing government (Osborne and Gaebler, 1992) as it is often a kind of conformance measurement in relation to the policies espoused in the plan.

In this paper I link the debate on how to conceptualise planning success to another debate of recent years - the success of Dutch national urbanisation planning. One position is that Dutch planning is a 'success story' (Alterman, 1997), and that the Netherlands is a 'planner's paradise' (Faludi and van der Valk, 1994). However, there are others who state that this paradise is lost (Bontje, 2003) and that planning is too weak (Hajer and Zonneveld, 2000) or that it is based on fiction rather than on reality (van Eeten and Roe, 2000; for a comment on this see Alexander, 2001).

In this paper the conceptualisation of planning success in terms of conformance and performance is used to analyse the success of the urban concentration policies set out in the "Fourth Memorandum on Spatial Planning-Plus" (also referred to hereafter by its Dutch acronym, VINEX), published between 1990 and 1993. This is done in light of the present debate on stagnation in Dutch housebuilding. This will give an insight into the applicability of concepts such as conformance and performance for measuring planning success as well as into the discussion as to whether Dutch planning is a success or not. 


\section{The measurement of success in planning}

The measurement of success of planning starts with the question 'what is planning?' (Talen, 1997). Alternatively, the question can also be stated as 'what type of planning are we going to evaluate?' (Mastop and Faludi, 1997). The two measures of success of planning in this paper correspond to two different answers to this question.

Looking for the right indicators is relevant, as Seasons explains in a recent paper on monitoring and evaluation in planning, in the Journal of the American Planning Association: "the right indicators would help planners in their efforts to explain issues, identify opportunities, provide better informed advice, and contribute to improved decision making" (2003, page 437). The discussion between conformance of plan and implementation and the performance of plans in promoting improvements in decisionmaking is an old discussion.

\subsection{The conformance principle}

According to the conventional approach (Faludi, 2000), planning effectiveness is measured by conformance between plan and implementation. The planning idea of final conformance can be stated as follows:

1. the object of planning is 'the world out there';

2. the plan provides the preferred solution; and

3. the plan is there to make this solution real.

Conformance between material developments and the plan is the criterion for success. This evaluation criterion is a good measure for 'project plans' (Faludi and van der Valk, 1994), "which provide blueprints of the intended end-state of the physical environment, including the measures necessary to achieve that state" (Mastop and Faludi, 1997, page 819). This planning measure could be used for simple plans but has also been used for strategic planning purposes in those cases where certainty prevails.

Conformance may be measured in absolute or in relative terms, that is, the extent to which "the original intentions were carried through to the final result" (Knudsen, 1988, page 552) is often used as a measure of success in planning.

According to Wildavsky, the conformance principle of plans will never hold:

"If planning were judged by results, that is, by whether life followed the dictates of the plan, then planning has failed everywhere it has been tried. Nowhere are plans fulfilled" (1987, page 8).

This statement has been proven incorrect, at least if a low margin of nonconformance is accepted.

Saglie and Sandberg (1997), for example, found $96 \%-98 \%$ of urban expansion in two Norwegian municipalities to be 'in accordance' with municipal master plans. The phrase 'in accordance with' is defined as 'at the same location and for the same land use' (that is, dwellings, shops, industry) as stated in the plans. In those two municipalities there was a pronounced political and administrative will to produce plans and to adhere to those plans. Planning as such was held in high esteem, as the legal position of municipal government was strong because government had the right to refuse building applications for plots outside the area for development as stated in the master plan. What was also relevant was that the municipalities were actively involved in 'direct development', a term used by the UK Environment Transport, and Regional Affairs Committee (ETRAC, 2000, page 13) for a situation in which government buys raw land, develops the infrastructure for housing development, and sells the plots to parties in the market. According to Saglie and Sandberg (1997), their study contradicts the theory that strategic municipal master planning does not work. There are cases and certain contexts in which planning works or, to be more precise, in which strategic planning sustains the criterion of conformance. 
The fact that conformance can be the case in strategic planning is relevant for the use of this criterion in evaluating planning. If no planning ever met the conformance criterion, and if this were the only criterion by which planning success could be measured, it might be better to abolish strategic planning straightaway instead of starting a 'mission impossible' to make plans that control development. There are, however, other reasons for using a different criterion for measuring planning success. This is because strategic planning is about other things, such as changing 'the world out there' based on, in all cases, a superior plan. For example, in a context of uncertainty, government learns as new information emerges, and, over time, this information may mean that it is wise to take decisions that are different from those set out in the plan.

\subsection{The performance criterion, or, measuring improvements in decisionmaking}

The alternative criterion is known as performance (Fudge and Barrett, 1981).

"Performance ... refers to how a plan fares during negotiations, whether people use it, whether it helps clarifying choices, whether ... the plan forms a part of the definition of subsequent decision situations. So what happens with the plan becomes the key to evaluation. Whether or not it is followed is not the issue" (Faludi, 2000, pp 305-306). This idea has been used to conduct several studies in the evaluation of planning (Mastop and Needham, 1997).

The idea and guiding principles of performance are as follows:

(a) the object of planning is not only 'the world out there' but also the justification of decisions taken by the planning subject to have an impact on the real world (for example, decisions in local zoning plans);

(b) knowledge available at the moment of taking operational decisions is superior to the knowledge at the time the plan was made; and

(c) plans are not meant to be coercive.

The result achieved through performance evaluation is better operational decisions, assessed by the justification of these decisions themselves in a communicative process (Faludi and Korthals Altes, 1994) and not the conformance between plan and results, as in conformance research. It is therefore about improving decisionmaking.

Subscribers to the plan interpret the plan by using their knowledge about the decision situation and apply any learning that has arisen since the plan was made. The plan may still be a framework for deliberations, but the act of simply following the plan is not a criterion of performance (contrast to Alexander and Faludi, 1989; Mastop, 2000), as following a poor plan does not improve decisionmaking nor has the plan proven to be a good investment in future decisionmaking. On the contrary, it can be an indicator of group think (Janis and Mann, 1977), as pressure for conformity is one of the symptoms of this phenomenon.

Performance research is more complex than conformance research. Faludi and I (Faludi and Korthals Altes, 1994) have proposed the following three-step research design:

1. identify the decisions that the plan should influence;

2. identify the commitments that are being made in these decisions, and identify the arenas in which these decisions are to be justified; and

3. answer the question as to whether all or part of the plan helped in "shaping the codes used in justifying subsequent decisions", and, if it has done so, whether the quality of the justifications concerned improved in terms of "taking account of the wider field of choice" (page 415).

This research design is based on additional thinking on the nature of good decisions and the role of planning in improving them. The first idea is that the quality of a decision is based on its justification (see Faludi, 1986); plan makers and plan users 
communicate to establish the meaning of the plan by using different codes, partly because the learning processes takes place in an uncertain environment. The second idea views the role of planning as a means of improving this justification process by placing individual decisions in a wider field of choice, based on the 'IOR School' (Friend and Jessop, 1969; Faludi and Mastop, 1982).

\subsection{Performance measurement}

This concept of performance in terms of improvement of decisions is a little different from the current, popular, practice of performance measurement. The idea of performance measurement is that an organisation defines its products and services and develops indicators to measure its output in a planning and control cycle in order to improve that organisation's performance (De Bruijn, 2002). Performance measurement fits into a broader concept of strategic management (Bryson, 2000). The objective is to focus government on improving results for citizens by measuring results in terms of outcomes that the citizens care about (Helling, 1998; Osborne and Gaebler, 1992).

In theory, performance measurement can be made in many ways, depending on the rationale behind the decision to measure performance (Behn, 2003); for instance, is performance measured in order to control subordinates or to celebrate successes? According to Behn (2003) there are eight different basic purposes of performance measurement, and each purpose requires a different criterion of performance measurement. So, in theory, both conformance and performance in terms of improving decisionmaking can be determined through performance measurement.

In practice, however, performance measurement is often indicated by easyto-measure outputs of an organisation, with the result that 'only that which is to be measured actually gets done' (De Bruijn, 2002). In this respect there are many anecdotes, especially from the Soviet Union, where the Gosplan of the State Planning Committee utilised performance measurement. One well-known anecdote relates how factory workers produced one 510-ton nail to meet their quota of 510 tons of nails! This effect is also not unfamiliar in recent practice (Courty and Marschke, 2003).

Abma and Noordegraaf (2003) argue that clear-cut performance targets are not appropriate in cases of ambiguity, defined as 'absence of or contradictory interpretations about what needs to, can and should be done, when and where', also known in the planning literature as 'uncertainty on values' (Friend and Jessop, 1969). This uncertainty over values is endemic in planning, as it is about balancing different territorial claims in a multiplayer setting in a given time-space context. It is for this reason that planning goes through a period of consensus-building (Innes, 1996). The development of valid and politically supported performance measurements often represent 'an Achilles heel' for strategic management in planning (Bryson, 2000).

In planning, a simple Gosplan-style performance measurement based on conformity between plan and output is relatively common. Seasons (2003, page 437) notes that many indicators (for example, numbers of units or time) used in the evaluation of plans did not help planners "in their efforts to explain issues, identify opportunities, provide better informed advice, and contribute to improved decision making". Planning evaluation is complex, as it is an attempt to address a number of different purposes. However, the main purpose of the evaluation methodology used here is to improve planning practice.

According to Behn (2003, page 597), for this purpose public managers need information from inside the black box on "how the inputs, environment, and operations they can change (influence or inspire) do (can, or might) cause (create, or contribute to) improvements in the outputs and outcomes". It is also an evaluation measure: what is 
relevant is that managers need a desired result with which to compare the data in order to judge performance. This objective is the basis of evaluation.

Therefore, the 'reinventing-government' style of performance measurement fits within the evaluation criterion of performance only if performance is measured in terms of reaching better operational decisions as measured by the justification of those decisions within a process of communication between decisiontakers and a community of interpretation.

The methodological concepts of conformance and performance have an impact on the evaluation of plans. In the next part of the paper the impact of the criterion of planning success on the analysis of planning processes is used to discuss the achievements of Dutch urbanisation planning.

\section{Dutch urbanisation planning}

The international community holds Dutch spatial planning in high esteem. Bolan (1999) is 'impressed by spatial planning achievements' in the Netherlands. Alterman (1997), in an international comparison of policies to conserve open areas, writes about a 'success story' and 'one of the most successful systems of planning and land management'. Wood (1998) calls the Netherlands a 'utopia' in his study on "vacant land in Europe". According to Hall (1997), the Netherlands has the 'worldwide lead' in the concurrence of spatial planning and transport planning. Mori (1998) is of the opinion that the Netherlands has a 'superbly efficient' system of spatial planning and building-land production. Schmidt-Eichstaedt (1999) writes positively about Dutch legislation that regulates compulsory purchase and the capacities of local government in land management. Voß (1997) takes the view that the Netherlands has managed to implement the golden rule of land production: land is offered in good time, for the proper functions, at a reasonable price (see also Needham, 1992). With reference to research and earlier sources of international admiration for Dutch planning [such as Hall (1966) in The World Cities, and Burke (1966) in the Greenheart Metropolis], Faludi and van der Valk (1994) therefore declared the Netherlands a 'planner's paradise' in their study of Dutch strategic spatial planning.

However, there are also critics taking a more negative view of Dutch planning. From an analysis of population developments, Bontje (2003) states that the Dutch 'planner's paradise' is lost. The successes date from the past and no longer apply. The idea of the Green Heart is more fiction than fact (van Eeten and Roe, 2000). The international image of a 'planner's paradise' also offsets current domestic feelings of a failing national spatial policy (see also Hajer and Zonneveld, 2000). The government, it is felt, ought to rectify planning failures by launching an authoritative Fifth Memorandum on Spatial Planning. According to Pronk, the former Minister for Spatial Planning, implementation is the weak spot: "Intentions and ideas went little further than the paper they were written on" (Financiële Dagblad 13 November 2000; see also NSPA, 2001, pages $9-10$ ). This statement is all the more remarkable as Minister Pronk is politically responsible for the fact that, within fourteen years of publishing the first draft of VINEX (Ministerie van VROM, 1990), over a million people would be living in new dwellings on VINEX-designated locations (Ministerie van VROM, 1999). The idea of an authoritative Fifth Memorandum has now changed. It is thought that planning in provinces and municipalities should be given greater importance than national planning.

Application of criteria for conformance and performance in planning may help to structure discussions, as described above. In this paper I do not use these criteria for a kind of holistic concept of Dutch planning but focus instead on Dutch national urbanisation policies, in which urban containment (that is, the concentration of urban development) is a dominant factor. 


\subsection{Dutch concentration policies as espoused in the plan}

VINEX is an amendment to the "Fourth Memorandum on Spatial Planning" (Ministerie van VROM, 1988), which was drafted because the government that had prepared the Fourth Memorandum fell, and the new government of Christian Democrats and Labour wanted to supplement the Fourth Memorandum with a 'Fourth Memorandum-Plus' (VINEX) in order to improve the environment, the liveability of town and country, and to encourage the implementation of the Fourth Memorandum.

VINEX stands in the middle of the traditional core issue in Dutch national urban planning [that is, the management of urban growth (see Korthals Altes, 1992)]. The conservation of the Green Heart is a cornerstone of this policy. Instead of outward expansion of the Randstad, the government has decided to intensify urban growth at the edge of the Randstad and, as a result, to enhance the contrast between the Randstad and the Green Heart.

The background to the concentration policies was that urban regions would function as compact daily urban systems. Concentration policies were there to maintain support for urban services, to limit mobility growth, to allocate housing, employment, and facilities in order to optimise accessibility by bicycle and public transport, and to contain the further urbanisation of rural areas (Ministerie van VROM, 1990, page 139). There were five criteria for the choice of locations within concentration areas.

First, development was to depend on location relative to the city centres: the first priority was to locate new development in inner-city areas; the second priority was those areas right on the edge of cities; only in the third instance were new locations to be developed at locations further from cities, but attached to existing centres of urbanisation. Second, developments were to be serviced by urban or regional public transport and slow traffic (within cycling distance to the centre). Third, development of housing, commercial areas, facilities, recreational areas, and green structure was to be coherent. Fourth, open areas were to be free from urbanisation to cater for the development of landscape, open-air recreation, and agriculture. Fifth, there were several features to the implementation, such as financial aspects, environmental aspects, aspects relating to administration, and societal aspects. VINEX sets out criteria for the choice of locations, and indications regarding the direction of urban development have been provided.

In January 1991, on the basis of VINEX, the Dutch government made an offer to the four largest Dutch urban regions (Korthals Altes, 1994; Needham and Faludi, 1999). This offer involved funds for housing, public transport infrastructure, and soil cleanup and depended on the city regions concerned developing housing locations and public transport infrastructure in accordance with the wishes of central government. Later the government also made offers to three other urban regions and to the provincial governments of another eighteen urban regions. Based on these offers, and following extensive negotiations, contracts between central government, seven urban regions, and eleven provinces were drawn up on the containment and development of urbanisation between 1995 and 2005. In accordance with these contracts, 456959 dwelling units were to be built in the twenty-six urban regions between 1995 and 2005 .

The 'theory' behind the policy is based on a number of daring assumptions (Needham and Faludi, 1999). These assumptions were as follows. First, lower-tier governments were willing to cooperate with national government in achieving growth-management objectives. Dutch municipalities are legally entitled to be autonomous. Central city municipalities and suburban municipalities have a history of conflict in urban regions in particular. The proposed solution for having seven city regions cooperate was a daring solution, both when it came to organisation at the local level and to political support at all government levels. Second, there was no fundamental 
change in the way housing development took place, apart from a more market-oriented housing programme. Third, there was sufficient market demand for the dwellings. Many questions were asked on this aspect. According to many critics, the building of a large percentage of housing in or near to cities, in relatively high densities, and the development of a larger percentage of more expensive housing was a daring strategy.

The VINEX policies were implemented at a time when the Dutch welfare state was being restructured and undergoing decentralisation. The context of planning was changing.

Dutch planning is based on a combination of planning by regulation, zoning, or 'planning by permission' (toelatingsplanologie), and of planning to facilitate development (ontwikkelingsplanologie). This dichotomy in planning styles and the idea that a combination of them is crucial to good planning is an essential element in Dutch planning practice (Siraa et al, 1995, page 29; see also Cals et al, 1966, page 195). The active intervention of government in guiding and orchestrating spatial investments does not replace the classical instruments of planning such as zoning but is an addition to these classical instruments. This successful tradition of spatial planning, and the combination of facilitating and prohibiting planning powers, rests on three cornerstones:

(1) within a framework of shared sustainable ideas on spatial planning, the endeavours of various authorities to reach a consensus on the (desired) spatial development and the way in which it should be achieved (the spatial planning doctrine; see Faludi and van der Valk, 1994);

(2) the willingness of higher authorities (the housing, transport, and public works sectors) to inject subsidies as part of spatial policy;

(3) the willingness of local authorities to conform and their ability to enforce the policy by buying and developing the raw land and implementing spatial developments autonomously (see Lefcoe, 1979; Needham, 1992).

Government subsidies were abolished in the 1990s (Priemus, 1995) and market parties abandoned their policies of not buying raw land (Korthals Altes, 2000). Although there is much debate on Dutch planning doctrine, this has not, until now, led to the doctrine being abandoned.

The complexity and the changes to the role of municipal government had an impact on the roles of municipal government and other players in urban development (Louw et al, 2003; Verhage, 2003). Growth in the proportion of market-sector housing meant an average increase in disposal prices for serviced land, which resulted in the early acquisition of land by developers at certain locations (Needham, 1997; Korthals Altes, 2000; Raaphorst et al, 1998).

\section{An analysis of the success of Dutch urbanisation planning}

\subsection{Conformance analysis of Dutch concentration policies}

Did the concentration policies succeed? The policy covenants for the concentration areas add up to a total growth of 456959 dwellings of housing stock in the concentration areas between 1995 and 2005. As can be seen from table 1 (over), between 1 January 1995 and 1 January 2004 the housing stock grew by 617659 dwellings. For table 1 we have used data on the covenants and the royal decree on location subsidies (Besluit locatiegebonden subsidies) of dwelling growth of the housing stock (Koninklijk Besluit, 1994).

Actual housing growth in the nine years between 1995 and 2004 (that is, $90 \%$ of the time) in the concentration areas amounted to $90.7 \%$ of the assignment for the decade $1995-2005$.

However, the figures given in table 1 are inflated, as the borders of the administrative units underwent change over the period. Urban municipalities gained territory, which meant they acquired more dwellings within their territories without any changes 
taking place in the built environment. As municipal boundaries change only at the turn of a year, these changes can be filtered out by comparing the annual changes in housing stock between 1 January and 31 December for each year, as in table 2 .

Table 1. Actual development of concentration (source: CBS, 2004).

\begin{tabular}{|c|c|c|c|c|c|c|}
\hline & \multicolumn{2}{|c|}{ Area of land ${ }^{\mathrm{a}}$} & \multicolumn{2}{|c|}{1995 housing stock ${ }^{\mathrm{b}}$} & \multirow{2}{*}{\multicolumn{2}{|c|}{$\begin{array}{l}\text { Housing-stock growth, } \\
1995-2004\end{array}$}} \\
\hline & \multirow{2}{*}{$\mathrm{km}^{2}$} & \multirow{2}{*}{$\%$} & \multirow{2}{*}{ no. } & \multirow{2}{*}{$\%$} & & \\
\hline & & & & & no. & $\%$ \\
\hline \multicolumn{7}{|l|}{ Concentration areas: } \\
\hline $\mathrm{BON}^{\mathrm{c}}$ - peformance & 3348 & 9.9 & 2189681 & 35.4 & 241696 & 39.13 \\
\hline other VINEX ${ }^{\mathrm{d}}$ & 3871 & 11.4 & 1554893 & 25.1 & 172743 & 27.97 \\
\hline subtotal & 7219 & 21.3 & 3744574 & 60.5 & 414439 & 67.10 \\
\hline \multicolumn{7}{|l|}{ Nonconcentration areas: } \\
\hline BON-other & 3188 & 9.4 & 370572 & 6.0 & 47287 & 7.66 \\
\hline other ${ }^{\mathrm{e}}$ & 23482 & 69.3 & 2076776 & 33.5 & 155933 & 25.25 \\
\hline subtotal & 26669 & 78.7 & 2447348 & 39.5 & 203220 & 32.90 \\
\hline $\begin{array}{l}\text { Total for the } \\
\text { Netherlands }\end{array}$ & 33889 & 100.0 & 6191922 & 100.0 & 617659 & 100.00 \\
\hline \multicolumn{7}{|c|}{$\begin{array}{l}\text { of Amsterdam, Rotterdam, The Hague, Utrecht, Enschede/Hengelo, Eindhoven/Helmond, and } \\
\text { Arnhem/Nijmegen. }\end{array}$} \\
\hline
\end{tabular}

Table 2. Growth of housing stock in concentration areas and in other areas (source: CBS, 2004).

\begin{tabular}{|c|c|c|c|c|c|c|}
\hline \multirow[t]{2}{*}{ Housing stock growth ${ }^{\mathrm{a}}$} & \multicolumn{2}{|c|}{ Concentration areas } & \multicolumn{2}{|c|}{ Other areas } & \multicolumn{2}{|c|}{ The Netherlands } \\
\hline & no. & $\%^{\mathrm{c}}$ & no. & $\%^{\mathrm{c}}$ & no. & $\%{ }^{c}$ \\
\hline Initial stock ${ }^{b}$ & 3744574 & 60.5 & 2447348 & 39.5 & 6191922 & 100 \\
\hline 1995 & 47960 & 57.0 & 36163 & 43.0 & 84123 & 100 \\
\hline 1996 & 46872 & 57.5 & 34652 & 42.5 & 81524 & 100 \\
\hline 1997 & 49092 & 59.2 & 33850 & 40.8 & 82942 & 100 \\
\hline 1998 & 51848 & 63.3 & 30003 & 36.7 & 81851 & 100 \\
\hline 1999 & 42143 & 62.6 & 25157 & 37.4 & 67300 & 100 \\
\hline 2000 & 38947 & 63.6 & 22302 & 36.4 & 61249 & 100 \\
\hline 2001 & 39998 & 68.0 & 18823 & 32.0 & 58821 & 100 \\
\hline 2002 & 34667 & 63.8 & 19667 & 36.2 & 54334 & 100 \\
\hline 2003 & 29813 & 65.5 & 15702 & 34.5 & 45515 & 100 \\
\hline Total, 1995-2004 & 381340 & 61.7 & 236319 & 38.3 & 617659 & 100 \\
\hline 'Administrative growth'd & $33099 \xi$ & ined & 33099 & & & \\
\hline Final stock ${ }^{\mathrm{e}}$ & 4159013 & 61.1 & 2650568 & 38.9 & 6809581 & 100 \\
\hline $\begin{array}{l}\text { a Growth from } 1 \text { January } \\
\text { b As of } 1 \text { January } 1995 . \\
\text { c Percentage relative to th } \\
\text { d Units added or lost as } \\
\text { e Housing stock in areas } \\
\text { adjusted for administrativ }\end{array}$ & $\begin{array}{l}\text { to } 31 \text { Decen } \\
\text { Netherland } \\
\text { result of ch } \\
\text { defined in }\end{array}$ & $\begin{array}{l}\text { er of the } \\
\text { total for } \\
\text { tges to a }\end{array}$ & $\begin{array}{l}\text { iven year. } \\
\text { te given ye } \\
\text { ninistrative } \\
\text { 1995) stock }\end{array}$ & nits. & over 195 & 004, \\
\hline
\end{tabular}


When the administrative changes have been filtered out the concentration results are less impressive but still show a net concentration towards the concentration areas. These policy results were not achieved overnight, with 1995, 1996, and 1997 showing no concentration, followed by a sharp rise in housing growth in concentration areas in 1998. However, the concentration was achieved mostly by containing housing growth in other areas. As a result, the basis for the achievements of Dutch concentration policies is in fact the stagnation of housing growth outside the concentration areas. The growth in the housing stock in other areas in 2003 was only $43 \%$ of the corresponding figure for 1995, whereas in the concentration areas the growth in 2003 was as high as $62 \%$ of that in 1995 .

This stagnation is reinforced by 'restrictive' policies in the 'planning-by-permission' style of planning. Early in the process, building capacity was retained in the statutory plans in nonconcentration areas. The approval of new building capacity outside the concentration areas has been more selective than in the past. This fits in with new endeavours at a national level regarding plan enforcement and the critical monitoring of provincial and municipal plans in relation to new building capacity.

We can see that conformance is high, and it is quite clear that VINEX policies had a considerable impact on this. Is this a planning success? Have the decisions on building improved or what has been the performance?

\subsection{From conformance to performance}

The relatively high conformance of Dutch concentration policies does not preclude criticism, and, in fact, a number of different aspects have come in for criticism: stagnation in the building of new housing in the Netherlands;

the underlying targets of the policy;

the quality of the locations; and

the working of market forces on the locations.

In this paper I focus on the issue of stagnation of dwelling production. This was a planned effect of the policies. The covenants show stagnation that is even more extreme, as they preferred two thirds of the building programme to be achieved before 1 January 2000; this would also mean that dwelling growth in the 2000-05 period would be half that of the $1995-2000$ period. The actual developments were not so extreme, as can be seen from table 2. Other critics state that there is now more at stake than stagnation alone. The criterion for performance analysis is whether the plan has played a role in improving the justification of decisions.

\subsubsection{Stagnation in housing production}

In the 1960s, 1970s, and 1980s housing production in the Netherlands was at over 100000 dwellings per year (figure 1, over). In the 1990s housing production fell to an average of 88000 dwelling per year. In recent years, housing production has fallen to an average of 70000 dwellings, with only 66704 new dwellings completed in 2002, which was an unprecedented low and last seen in 1955. In addition, production is running at less than $1 \%$ relative to total housing stock. The last time this happened was in 1947, a few years after the end of the Second World War, when building materials were in short supply and priority was given to renovating the existing housing stock. The average production between 1950 and 2000 was $2.5 \%$. The golden rule of land development for housing (Voß, 1997) — that is, to produce a good amount of housing at the appropriate time - is no longer working.

Stagnation leads to an ever greater shortage of dwellings. The quantitative housing shortage nearly doubled between 1998 and 2002, from 1.3\% to 2.5\% (Ministerie van VROM, 2002). Housing need is on the increase relative to housing stock. The lack of housing production has consequences for movements on the 'housing ladder' and 


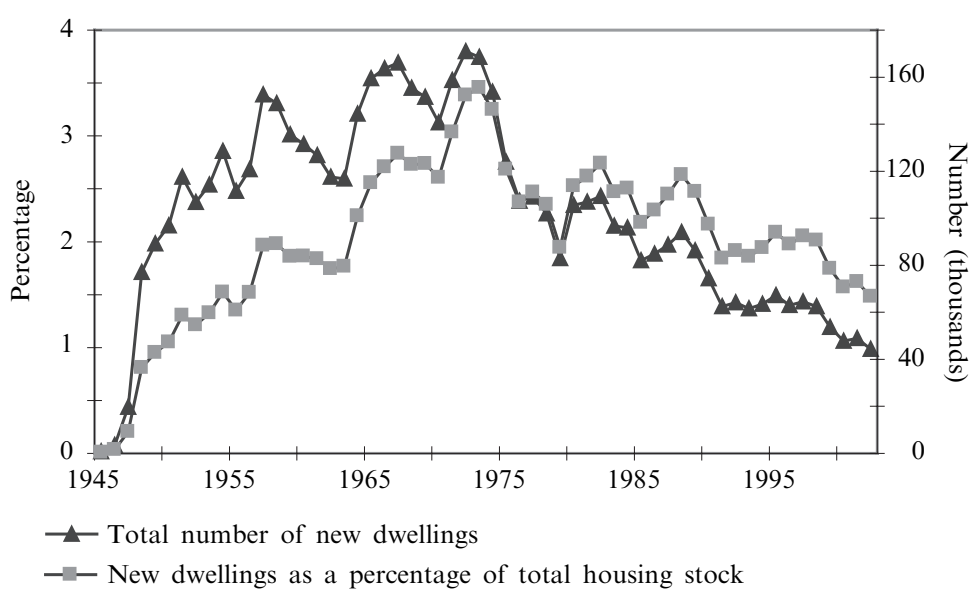

Figure 1. New dwellings built in the Netherlands: absolute number, and relative to the total housing stock (source: CBS, 2003).

consequently for the dynamics of housing markets. Many households do not move simply because the housing market chains created by new dwellings are not creating sufficient 'pull'.

What is relevant is that houses that do get a building permit are, on average, larger than those in the past. In 1990, the average size of a dwelling with a building permit was $404 \mathrm{~m}^{3}$, whereas in 2002 this figure was $504 \mathrm{~m}^{3}$ (CBS, 2004). The dwellings are some $25 \%$ larger. Houses for rent are $29 \%$ larger, and houses for sale $17 \%$ larger. The strict quality control on the social rented sector to prevent the need for high central government grants since the abolition of social housing grants in 1995 (Priemus, 1995), has led not only to a much smaller share of social rented housing but also to an improvement in the quality of the dwellings.

4.2.1.1 Dutch stagnation in dwelling growth in a Western context

As stated in section 4.1, low housing production in the Netherlands fits in well with the VINEX policy of the early 1990s. Were the targets so low, however, and can this stagnation be placed in a Western context of housing completion?

Housebuilding in the Netherlands is historically low (in 2002 it fell below 1\%), but it is not the lowest in the EU (table 3). Housing completions in the EU are also low in comparison with levels in the USA. According to US Census Bureau (2002) data, about 2.38\% of housing units in 2001 were built between 1999 and March 2000. This amounts to a housing stock growth of $1.9 \%$ a year. However, there are large regional differences. The average for New England, New York, New Jersey, Pennsylvania, Maryland, Delaware, and Washington, DC, is only $0.98 \%$. The average for California is $1.25 \%$. The average in Nevada, Colorado, Utah, New Mexico, and Arizona is $3.67 \%$. The Dutch housing production numbers are therefore comparable with the northeast of the USA.

Production levels in Sweden continue to be low. Low production was already evident in 1990, with dwelling completions at an average of $0.3 \%$ of the dwelling stock over the 1990s (Statistics Sweden, 2003). According to Boverket (the National Board of Housing, Building and Planning) - the Swedish government agency for planning, the management of land and water resources, urban development, building, and housing, this "very low production" (Boverket, 2000, page 6) means a housing shortage, in particular in the three metropolitan areas of Stockholm, Göteborg, and Malmö. Currently, "the situation is getting to be very problematic". According to a government 
Table 3. Dwelling completions as a percentage of total dwelling stock for countries in the European Union, 2000 (source: Sak and Raponi, 2002).

\begin{tabular}{ll}
\hline Country & Percentage \\
\hline Ireland & 3.85 \\
Portugal & 2.28 \\
Spain & 1.96 \\
Greece & 1.90 \\
Luxembourg & 1.84 \\
Austria & 1.49 \\
Germany (old states) & 1.43 \\
Finland & 1.33 \\
France & 1.08 \\
Netherlands & 1.07 \\
Belgium & 0.98 \\
United Kingdom & 0.74 \\
Denmark & 0.63 \\
Italy & 0.61 \\
Sweden & 0.29 \\
\end{tabular}

study, the annual production of housing must "yearly rise considerably in comparison to what the municipalities expected if economic growth was not to be threatened" (Boverket, 2000). So this is also considered to be a problem.

In the United Kingdom, and also in its constituent countries such as England, these figures have been low for a longer period. The ten year average of 145000 new dwellings in England amounts to about $0.7 \%$ of the housing stock. Evans (2003) explains this low housing production in the United Kingdom by pointing first to the planning system "that can be, and is used to block and delay development" (2003, page 203). Second, he mentions the British attitude towards undeveloped land, that greenfield sites are extremely scarce and should be conserved. Third, he states that the British tend to be interested "in their neighbour's doings, which is an attitude that helps to ensure that there will be objections to almost any proposal for development and that different coalitions will form to try to block developments" (page 203). According to Evans, this is at odds with the perception of other nationalities that development is a demonstration of economic progress and that there is sufficient land available.

Evans also points to the Italian example, where many houses are built without planning permission. This is perhaps one of the explanations for the low official figures on dwelling completions in Italy.

In an international context, Dutch housing completions are thus relatively low, but not exceptionally low. The problem of the stagnation in housing production can also be felt elsewhere, so the problem of such stagnation is not unique to the Netherlands.

\subsubsection{Stagnation and policies}

In a new housing policy report at the beginning of 2001 the Ministry of Housing, Spatial Planning and the Environment had the ambition to build 950000 dwellings between 2000 and 2010 (Ministerie van VROM, 2001, page 183). Part of this is to be replacement of existing stock. However, the ambitions were much higher than the previous ambitions stated in VINEX. The need for greater ambitions was already clear in 1994, only four years after the publication of VINEX (Faludi and Korthals Altes, 1996). The 2001 ambitions were not achievable. A housing-production taskforce was commissioned to analyse the causes of the stagnation in housing production 
and to give advice on how to encourage higher production levels. According to the taskforce, the causes of the stagnation (Taskforce Woningbouwproductie, 2002) were:

(a) multiplicity, complexity, lack of transparency, and discretionary changes in policies and rules;

(b) local government proceedings and the 'directive role' of local governments; and

(c) insufficient levels of personnel in the market and in government agencies for housing projects (unemployment in the Netherlands was low; there were many vacancies, both in local government agencies and for skilled workers in the building sector).

The national government has promoted actions to be taken in these areas. There is a new offensive to change the rules. It is now too early to say whether this will actually reduce red tape or whether this will replace the rules by a new, even more complex, system of rules. Research has been commissioned to gain better insight into the 'directive role' of municipalities (Korthals Altes et al, 2003; see also Louw et al, 2003). For certain locations the national government offered help from specialists in 'housing boost teams' (aanjaagteams) to overcome stalemate situations in housing production. There are cases in which local government civil servants say that this worked (Korthals Altes et al, 2003, page 47). Dekker (2003, page 15), Minister of Housing, Spatial Planning and the Environment, evaluates these activities positively and she is continuing the activities of these teams. Nevertheless, housing production remains low, and in September 2003 she lowered the ambitions to 80000 dwellings to be built every year between 2005 and 2010 (Dekker, 2003).

Returning to the theme of performance, the following conclusions can be drawn. VINEX does not contribute anything towards the discussion surrounding breaking the stagnation in housebuilding; moreover, this stagnation was planned stagnation. National government was so certain about future housing needs that it made binding agreements for a ten-year period and also made a substantial commitment to stop development outside the specified areas.

Also, as Jaap Modder, the chairman of the executive of the Arnheim-Nijmegen urban region states, Dekker has no instruments left with which to stimulate housing production: "the only thing she can do is to smooth talk her way through the Netherlands in the hope of driving housing production up again"(1) (Aerts, 2003). By doing so, the policy to make covenants for ten years and to put all grant money into these covenants sacrificed flexibility for the creation of new policies.

In total, over $€ 900$ million in grants have been allocated to the provinces and urban regions to fund the gap for the losses in developing the VINEX areas. The funds were necessary as these locations were not only on simple rural sites but also were sometimes used for more intensive purposes, such as an airport at Ypenburg near The Hague, for greenhouses, as at Wateringse Veld in The Hague, Leidsche Rijn in Utrecht (Verhage, 2003), and Waalsprong near Nijmegen, or for land reclamation, as in IJburg Amsterdam. Research into costs and benefits from the early 1990s formed the basis of these grants. In 2000, research established that these grants were, generally speaking, not necessary as market developments made it possible to finance the costs (Kolpron, 2000).

\subsubsection{Further criticism of the policies}

The approach that was chosen, with its implementation covenants, is characterised by less flexibility compared with other possible approaches. This is currently becoming clear from the discussions regarding the quality of the VINEX locations. The implementation model

(1) Zij kan alleen nog zalvend door Nederland gaan om zo de woningbouwproductie weer omhoog te krijgen. 
adopted apparently has insufficient possibilities for anticipating changes to the national government's ambition (PWVIJNO, 2000; see also Bontje, 2001, page 132).

Moreover, whether the underlying targets of the policies have been reached is currently under discussion. Geographers tend to evaluate the Dutch concentration policies not according to the operational criteria used by the policies themselves (that is, housing growth) but on the underlying goals of population concentration and economic activities. Bontje shows, for example, that, although Dutch population distribution policies are "a reasonably successful policy" (2001, page 133), the successes were achieved mainly in the years prior to 1985 .

Politicians have criticised the dominant role developers could play by buying land (PWVIJNO, 2000). However, the Netherlands Competition Authority (NCA, 2001) established that nowhere could developers get a dominant market position in regional markets for housing development or in new housing markets. Nevertheless, this development does have an effect on the municipalities, as the politicians in the municipal executive can no longer freely choose the developers with whom they wish to cooperate. Instead, they have to deal with the developers that purchased the land; the municipal politicians consider this to be an inconvenient monopoly of a developer in 'their' area.

Urban designers are more critical of the quality of the development locations. According to a recent article in The New York Times, the so-called VINEX developments consist of "plenty of unremarkable architecture" in a nation "that has set the international design standard for everything" (Hawthorne, 2004, section F, page 1). As suburbs tend to look the same, there is criticism of the quality of the location. What is relevant here is that there are a number of relatively large locations, such as Leidsche Rijn (30 000 dwellings), Waalsprong (13000 dwellings), IJburg (18 000 dwellings), Ypenburg (11000 dwellings), and Vathorst (11000 dwellings), and many others in the $5000-10000$ dwellings range. In the new polder town of Almere about 3000 dwellings are produced on various locations each year. The massive development of these locations fuels the criticism of uniformity and lack of identity. Dutch civil servants often literally speak about 'putting dwellings down' (woningen wegzetten) (Platform Zuidvleugel, 2003, page 23) on a particular location. This jargon and the way of thinking behind it fits in well with quantitative policies on housing growth but not with policies directed at the qualitative development of the housing sector.

According to Bontje, the VINEX areas internally manifest a considerable variety in architecture and housing type, but externally all the areas "seem to look almost identical throughout the country" (2001, page 127). The locations are characterised as 'neither urban nor really suburban'. Critics state that the houses are too small, too uniform, and in too high a density to attract suburban-oriented households (Musterd, 1999).

Research based on statements by people who live in the VINEX areas, compared with people who live in other areas, suggests that the quality of VINEX areas is not worse and is maybe even slightly better than other new locations (van Iersel and Marsman, 1999). Only some locations in the Randstad are an exception to this, where, when the research was conducted, the market was so overheated that even bad-quality dwellings could be sold for a good price. This is something that has changed in recent years. In the more expensive tier of the housing programme in particular, consumers are critical when it comes to quality, and housing programmes that do not deliver that quality simply do not sell (see also Dol and van der Heijden, 2003). Nowadays, there is much debate on the concept of producing housing over a large area, because the 'mass' of urban extension areas has an impact on the quality of living and services. 


\subsection{Analysis of the performance of the plan}

In this section I analyse the performance of Dutch urbanisation policies in relation to the stagnation of housing production by means of three-step research design devised with Faludi (Faludi and Korthals Altes, 1994; see also section 2.2).

The first step is to identify the decisions that the plan should influence. The idea is that the plan is not only a framework for the implementation contract but also helps in setting policies to overcome stagnation in housebuilding. A strategic plan for urbanisation in the coming decades must meet changing demands during those years because of uncertain demand. It must also be able to adapt to changes in both spatial and sectoral policy views as new governments take office. Although changes in demands and political priorities are foreseeable, the direction of change remains uncertain.

The second step is to establish the commitments that are being made and to determine the arenas in which these commitments are to be justified. The commitment entered into was to conclude contracts with city regions and provinces on the housing programme between 1995 and 2005. New policies were then introduced and, for the 2005-10 period, local governments were asked to prepare plans based on high forecasts of need (Faludi and Korthals Altes, 1996).

The contracts for the 1995-2005 period did not cater for changes in demand. Moreover, because locations and housing size were specified, neither did they have the flexibility to meet known demands by preparing excess plan capacity when housing production at one location stagnated. One exception to this was the Amsterdam region, which requested precisely that, in view of major land reclamation in a lake. The formal justification of the contracts took place in parliament, which not only received copies of the contracts but also on numerous occasions debated the policies with the minister. A parliamentary commission also put much effort into critically assessing the policy, including the negotiating model (PWVIJNO, 2000, pages 154-174). The policy also attracted criticism from outside formal circles, among professionals, and in articles in general newspapers and magazines. The government policies to overcome the stagnation in the production of housing have been the subject of debate in the same arenas.

The third step is to assess how the plan performed in relation to making subsequent decisions. There is a clear, strong, relationship between VINEX and the commitments made in the implementation contracts (PWVIJNO, 2000, appendices, page 199). However, it is questionable whether this strong commitment was necessary and whether it would have been more helpful if the plan had involved a less prescriptive type of contract, allowing room for extra housing production in response to demand:

"the approach of using covenants for the implementation of planning policy lacks flexibility. ... And ... due to constantly changing estimates of housing need, ... covenants offer anything but the much sought-after certainty" (Korthals Altes, 1995, $301-302)$.

The problem is that the Dutch national government cannot simply withdraw from urbanisation policies for a decade by doing no more than checking whether performance targets are being met. Political reflection on new knowledge on housing needs and new political aspirations, also involving related policy fields, is considered necessary in the Dutch context. VINEX plays hardly any role in the debate on housing stagnation, because the stagnation relates to ambitions that were conceptualised only after the contracts had been concluded. A sign of this nonperformance is that the updated version of VINEX, which is still the current policy, is not available on the website of the Ministry of Housing, Spatial Planning, and the Environment, in stark contrast to its extensive coverage of other issues (De Rooij, 22 September 2004, personal communication). ${ }^{(2)}$

(2) E-mail from A J De Rooij, web manager of the website of the Ministry of Housing, Spatial Planning and the Environment, from internet@minvrom.nl. 


\section{Conclusions}

The practice of Dutch urban containment policies shows that conformance between plan and urban development is not always a good measure of success in planning. Although Dutch urban development follows the planning made in the early 1990s astonishingly well, VINEX has not been successful in light of the present debate on housing stagnation and does not help to overcome that problem because the housing stagnation was actually planned. Moreover, the use of ten-year covenants with fixed agreements did not fit in well with the flexibility of political agendas or with market developments in terms of costs and benefits of development.

The Dutch case shows that the performance criterion is an independent measure of the success of a plan. The question, then, is whether the plan played a role in arriving at better justification of subsequent decisions. Performance in that sense is something very different from the popular practice of performance measurement. Although in theory the performance criterion can form a part of performance practice, in real terms it is conformance with respect to clear-cut targets that is generally measured.

The criterion of performance fits in well within an uncertain context where agencies learn and know that the knowledge incorporated in the plan is not superior to knowledge that comes to light at a later stage when decisions are taken on spatial development projects.

Conformance between plans and subsequent developments is not a measure of performance in terms of improving the justification of later decisions. These insights have implications for further research into the evaluation of plans. The idea that with the criterion of conformance evaluators possess a "tangible, objective measure of planning success" (Talen, 1997, page 577) loses ground when conformance to the plan is seen as a failure of the planning system to adopt and take up new challenges. This was true in the Dutch case for its national plan for urbanisation policies. The changes in society, and in the housing market and policies in particular, have rendered the question of whether the plan has been followed irrelevant.

\section{References}

Abma T A, Noordegraaf M, 2003, "Public managers amidst ambiguity: towards a typology of evaluative practices in public management" Evaluation 9 285-306

Aerts J, 2004, "Minister kan weinig uitrichten bij bouw te weinig huizen in regio" [Minister cannot accomplish much in building too few houses in region] De Gelderlander 12 March 2004, http://www.krantenonline.nl/regioportal/WEM/1,3112,2637_2053441_,00.html

Alexander E R, 2001, "Netherlands planning: the higher truth" Journal of the American Planning Association $6791-92$

Alexander E R, Faludi A, 1989, "Planning and plan implementation: notes on evaluation criteria" Environment and Planning B: Planning and Design $16127-140$

Alterman R, 1997, "The challenge of farmland preservation: lessons from a six-nation comparison" Journal of the American Planning Association 63220 - 243

Behn R D, 2003, "Why measure performance? Different purposes require different measures" Public Administration Review $63586-606$

Bolan R, 1999, "The Dutch retreat from the welfare state and its implications for metropolitan planning" AME Essays from Visiting Professors University of Amsterdam, Amsterdam

Bontje M, 2001 The Challenge of Planned Urbanisation and National Urbanisation Policy in the Netherlands in a Northwest-European Perspective PhD thesis, University of Amsterdam, Amsterdam

Bontje M, 2003, 'A 'planner's paradise' lost? Past present and future of Dutch national urbanization policy" European Urban and Regional Studies $10135-151$

Boverket, 2000, "The regular national report on housing development in Sweden", Boverket (National Board of Housing, Planning and Building), Karlskrona, http://www.boverket.se/ novo/filelib/personal/hangus/eunationalreporttilleu000619.doc 
Bryson J M, 2000, "Strategic planning and management for public and nonprofit organizations and communities in the United States", in The Revival of Strategic Spatial Planning Eds W Salet, A Faludi (Royal Academy of Arts and Sciences, Amsterdam) pp 205-217

Burke G, 1966 Greenheart Metropolis: Planning in the Western Netherlands (Macmillan, London)

Cals J, Bogaers P, Samkalden I, Diepenhorst I A, Vondeling A, Bot Th H, Suurhoff J G, Den Uyl J M, Biesheuvel B W, Veldkamp G M J, Vrolijk M, 1966 Tweede nota over de ruimtelijke ordening in Nederland [Second memorandum on spatial planning] (Staatsuitgeverij, 's-Gravenhage)

CBS, 2004, "Regionale kerncijfers Nederland" [Regional key figures Netherlands], Centraal Bureau voor de Statistiek, http://statline.cbs.nl

Courty P, Marschke G, 2003, "Dynamics of performance-measurement systems" Oxford Review of Economic Policy 19268 - 284

De Bruijn H, 2002, "Performance measurement in the public sector: strategies to cope with the risks of performance measurement" International Journal of Public Sector Management 15 $578-594$

Dekker S M, 2003, "Brief van de Minister van Volkshuisvesting, Ruimtelijke Ordening en Milieubeheer" [Letter from the Minister of Housing, Spatial Planning and the Environment] Kamerstukken 70655, 29200 XI, number 3 (SDU, The Hague)

Dol C P, van der Heijden H M H, 2003, "Monitor Nieuwe Woningen tot en met het vierde kwartaal 2002" [Monitor of new dwellings up to fourth quarter 2002], Onderzoeksinstituut OTB, Delft, http://www.monitornieuwewoningen.nl/html/rapportages/rprtg.html

ETRAC, 2000 The Implications of the European Commission Ruling on Gap Funding Schemes for Urban Regeneration in England Environment, Transport, and Regional Affairs Committee, House of Commons, 16th report of session 1999-2000, HC 714 (The Stationary Office, London); http://www.publications.parliament.uk/pa/cm199900/cmselect/cmenvtra/714/71402.htm

Evans A W, 2003, "Shouting very loudly: economics, planning and politics" Town Planning Review $74195-212$

Faludi A, 1986 Critical Rationalism and Planning Methodology (Pion, London)

Faludi A, 2000, "The performance of spatial planning" Planning Practice and Reserach 15 299-318

Faludi A, Korthals Altes W, 1994, "Evaluating communicative planning: a revised design for performance research" European Planning Studies 2403 - 418

Faludi A, Korthals Altes W, 1996, "Marketing planning and its dangers: how the new housing crisis in The Netherlands came about" Town Planning Review 67 183-202

Faludi A, Mastop J M, 1982, "The 'IOR school': the development of a planning methodology" Environment and Planning B: Planning and Design $9241-256$

Faludi A, van der Valk A J, 1994 Rule and Order: Dutch Planning Doctrine in the Twentieth Century (Kluwer Academic, Dordrect)

Friend J K, Jessop W N, 1969 Local Government and Strategic Choice (Tavistock Publications, London)

Fudge C, Barrett S, 1981, "Reconstruction of the field of analysis", in Policy and Action: Essays on the Implementation of Public Policy Eds S Barrett, C Fudge (Methuen, London) pp 249-278

Hajer M, Zonneveld W, 2000, "Spatial planning in the network society-rethinking the principles of planning in the Netherlands" European Planning Studies 8337 - 355

Hall P, 1966 The World Cities (Widenfeld and Nicolson, London)

Hall P, 1997, "The future of the metropolis and its form" Regional Studies $31211-220$

Hawthorne C, 2004, "The Dutch retouch suburbia" The New York Times 15 January, late edition, section $\mathrm{F}$, page 1

Helling A, 1998, "Changing intra-metropolitan accessibility in the US: evidence from Altanta" Progress in Planning $4955-107$

Innes J E, 1996, "Planning through consensus building: a new view of the comprehensive planning ideal" Journal of the American Planning Association 62460 - 472

Janis I L, Mann L, 1977 Decision Making; A Psychological Analysis of Conflict, Choice, and Commitment (The Free Press, New York)

Koninklijk Besluit, 1994, "Besluit van 26 januari 1994, houdende regels betreffende de verlening en uitbetaling van geldelijke steun voor de ontwikkeling van bouwlocaties" [Decree of 26 January 1994 concerning rules on grants for development of housing locations], Staatsblad, 26 January, issue 57 , pages $1-29$

Knudsen T, 1988, "Success in planning" International Journal of Urban and Regional Research 12 $550-565$ 
Kolpron, 2000 Kostenverhaal in de grondexploitatie op VINEX-locaties [Recovery of costs of infrastructure provision on VINEX-locations] Neprom, Voorburg,

http://www.neprom.nl/publicaties/publicaties.html

Korthals Altes W K, 1992, "How do planning doctrines function in a changing environments" Planning Theory 7-8 110-115

Korthals Altes W K, 1994, "Preparing for performance: the Dutch experience" European Spatial Research and Policy $177-85$

Korthals Altes W K, 1995 De Nederlande Planningdoctrine in het fin de siècle [Dutch planning doctrine in the fin de siècle] (Van Gorcum, Assen)

Korthals Altes W, 2000, "Economic forces and Dutch strategic planning", in The Revival of Strategic Spatial Planning Eds W Salet, A Faludi (Royal Academy of Arts and Sciences, Amsterdam) pp 67-77

Korthals Altes W K, Nieuwenhuizen S, Stevens M, Harkes N, 2003, "Organisatie van prestatie: Regie in de stedelijke ontwikkeling. Hoofd- en achtergrondrapportage" [Organisation of performance: the directive role in urban development], ECORYS - Kolpron, Rotterdam, http://www.kei-centrum.nl/files/kei2003/documentatie/ecorys-regierolgemeentenachtergrondrapportage-131003.pdf

Lefcoe G, 1979 Land Development in Crowded Places: Lessons from Abroad (The Conservative Foundation, Washington, DC)

Louw E, van der Krabben E, Priemus H, 2003, "Spatial development policy: changing roles for local and regional authorities in the Netherlands" Land Use Policy 20 357-366

Mastop H J M, 2000, "The performance principle in strategic planning", in The Revival of Strategic Spatial Planning Eds W Salet, A Faludi (Royal Academy of Arts and Sciences, Amsterdam) pp $143-155$

Mastop H, Faludi A, 1997, "Evaluation of strategic plans: the performance principle" Environment and Planning B: Planning and Design $24815-832$

Mastop H, Needham B, 1997, "Performance studies in spatial planning: the state of the art" Environment and Planning B: Planning and Design 24881 - 888

Ministerie van VROM, 1990 Vierde nota over de ruimtelijke ordening Extra: Deel 1 Ontwerp PKB nationaal ruimtelijk beleid (Fourth Memorandum on Spatial Planning Plus) Ministerie van Volkshuisvesting, Ruimtelijk Ordening en Milieubeheer (SDU, The Hague)

Ministerie van VROM, 1988 Vierde nota over de ruimtelijke ordening: deel 1 beleidsvoornemen [Forth Memorandum on Spatial Planning] Ministerie van Volkshuisvesting, Ruimtelijk Ordening en Milieubeheer (SDU, The Hague)

Ministerie van VROM, 1999, "Rapportage monitoring uitvoering verstedelijking Vinex" [Report of the monitoring of the implementation of the VINEX urbanization], Ministerie van Volkshuisvesting, Ruimtelijk Ordening en Milieubeheer, Rijnstraat 8, The Hague

Ministerie van VROM, 2001, "Mensen, Wensen, Wonen" [People, desires, to reside], Ministerie van Volkshuisvesting, Ruimtelijk Ordening en Milieubeheer Kamerstukken kst50478, 27559, number 2 (SDU, The Hague)

Ministerie van VROM, 2002, "Gescheiden markten? De ontwikkelingen op de huur en koopwoningenmarkt", Ministerie van Volkshuisvesting, Ruimtelijk Ordening en Milieubeheer, Rijnstraat 8, The Hague

Mori H, 1998, "Land conversion at the urban fringe: a comparative study of Japan, Great Britain and the Netherlands" Urban Studies 351541 - 1558

Musterd S, 1999, 'De identiteit van woonmilieus" [The identity of residential environments], in Voorbij de compacte stad? [Beyond the compact city?] Eds F M Dieleman, S Musterd (Van Gorcum, Assen) pp 49-62

NCA, 2001, "Besluit in de zaaknummer 1655; onvolkomen marktwerking op Vinex-locaties" [Insufficient operation of market forces in 'Vinex' locations], 12 September, Netherlands Competition Authority, The Hague, http://www.nmanet.nl/nl/nieuws en publicaties/dossiers/ dossier_bouwsector/mededingingswet/machtsposities.asp

Needham B, 1992, "A theory of land prices when land is supplied publicly" Urban Studies 29 $669-681$

Needham B, 1997, "Land policy in the Netherlands" Tijdschrift voor Economische en Sociale Geografie $88291-296$

Needham B, Faludi A, 1999, "Dutch growth management in a changing market" Planning Practice and Research $14481-491$ 
NSPA, 2001, "Summary: making space, sharing space — fifth national policy document on spatial planning 2000/2020", Ministerie van Volkshuisvesting, Ruimtelijk Ordening en Milieubeheer (Rijnstraat 8, The Hague)

Osborne D, Gaebler T, 1992 Reinventing Government: How the Entrepreneurial Spirit is Transforming the Public Sector (Addison-Wesley, Reading, MA)

Platform Zuidvleugel, 2003 De Zuidvleugel van de Randstad, Conferentieversie [The Southern Wing of the Randstad, conference version] (Zuidvleugelbureau, The Hague)

Priemus H, 1995, "How to abolish social housing - the Dutch case" International Journal of Urban and Regional Research $19145-155$

PWVIJNO, 2000, "Notie van ruimte: op weg naar de Vijfde Nota ruimtelijke ordening; Verslag van het onderzoek" [Notion of space, towards a Fifth memorandum on spatial planning, research report], Parlemantaire werkgroep vijfde nota Ruimtelijke Ordening Kamerstukken TK 1999-2000, 27210, numbers $2-3$ (SDU, The Hague)

Raaphorst T, Platte H, Korthals Altes W K, 1998, "Prijzen grondverwerving van Vinex-locaties" [Prices land acquisition on VINEX locations], in Handboek grondbeleid en locatieontwikkeling Eds J de Jong, G H J Oude Vrielink, L C Groen, W K Korthals Altes, H W de Wolff, G Verkerk (Elsevier Bedrijfsinformatie, The Hague) section C.543, supplement 81, pp 53-62

Saglie I L, Sandberg S L, 1997, “Urban expansion in Norway-development by plan?” Scandinavian Housing and Planning Research $1451-70$

Sak B, Raponi M, 2002, "Housing statistics in the European Union 2002", Direction Générale de l'Aménagement du Territorire, du Logement et du Patrimoine, Namur, http://mrw.wallonie.be/ dgatlp/dgatlp/Pages/log/DwnLd/Stats2002/housingStats2002.pdf

Schmidt-Eichstaedt G, 1999, "Baulandbereitstellung nach dem niederländischen Modell" [Production of building land according to the Dutch model] Grundstücksmarkt und Grundstückswert 10 $65-72$

Seasons M, 2003, "Monitoring and evaluation in municipal planning" Journal of the American Planning Association $69430-440$

Siraa H T, van der Valk A J, Wissink W L, 1995 Met het oog op de omgeving [An eye to the environment] (SDU, The Hague)

Statistics Sweden, 2003 Statistical Yearbook of Sweden 2003 (Offical Statistics of Sweden, Örebro)

Talen E, 1997, "Success, failure, and conformance: an alternative approach to planning evaluation" Environment and Planning B: Planning and Design $24573-587$

Taskforce Woningbouwproductie, 2002, "Achterblijvende woningbouwproductie: problematiek en maatregelen", http://www.kei-centrum.nl/files/stedelijkevernieuwing/artikelen/pub-achterblijvende _woningproductie-taskforce.pdf

US Census Bureau, 2002 American Housing Survey for the United States: 2001 Current Housing Reports Series H150/1 (US Government Printing Office, Washington, DC)

van Eeten M, Roe E, 2000, "When function conveys truth and authority" Journal of the American Planning Association $6658-67$

van Iersel J, Marsman G, 1999, "VINEX-kwaliteit door de ogen van bewoners" (VINEX quality in the eyes of the inhabitants), RIGO, Amsterdam, http://www.rigo.nl/Rapporten/73720.pdf

Verhage R, 2003, "The role of the public sector in urban development: lessons from Leidsche Rijn Utrecht (the Netherlands)" Planning Theory and Practice $429-44$

Voß W, 1997, "Niederlande", in Boden-Wem nutzt er? Wen stützt er? Neue Perspektiven des Bodenrechts Bauwelt Fundamente 119, Eds B Dieterich, H Dieterich (Vieweg, Braunschweig) pp $109-123$

Wildavsky A, 1987 Speaking Truth to Power: The Art and Craft of Policy Analysis 2nd edition (Transaction Publishers, New Brunswick, NJ)

Wood B, 1998, "Vacant land in Europe", WP 98BW1, Lincoln Institute of Land Policy, 113 Brattle Street, Cambridge, MA 02138 
Conditions of use. This article may be downloaded from the E\&P website for personal research by members of subscribing organisations. This PDF may not be placed on any website (or other online distribution system) without permission of the publisher. 